\title{
TAX MOTIVATION AS AN INSTRUMENT PROTECTING PUBLIC FINANCIAL INTEREST
}

\author{
EWA LOTKO
}

\begin{abstract}
This article analyses tax motivation to fulfill tax obligation through the prism of public interest (financial). The starting point for the research presented here are factors shaping taxpayers motivation to comply with tax obligation or evade it. The aim of the article is to determine what values guide taxpayers deciding to pay or evade due taxes as well as what factors shape their tax motivation. The research problem is to establish the answer to the question whether tax motivation may protect the public financial interest. Regarding obtained results of the research identifying factors shaping tax motivation, psychological and ethical factors were selected, with the former proved to be major in having an impact on tax motivation. The main psychological factor negatively influencing tax motivation is the amount of tax and general reluctance towards transferring a part of the earned money.
\end{abstract}

\section{Keywords}

Public interest; tax motivation; tax morale; tax; public financial interest

JEL Classification: A14, H30, H60

\section{Introduction}

Taxpayer's attitudes and beliefs to fulfill tax obligations are the subjects of analysis mainly of social psychologists (Niesiobędzka, 2013: 11-66). They conduct research on the so-called tax morale defined as "attitudes of a group or the whole population

1 Doctor of Law, assistant in the Department of Public Finances and Financial Law on the Faculty of Law University of Bialystok. The Author of a few dozens of publications on public finances including instruments limiting deficit and public debt as well as participatory budgeting. A member of the Center for Information and Research Organisation in Public Finance and Tax Law of Central and Eastern European Countries, Editor-inChief of the research journal "Annual Center Review". Contact email: e.lotko@uwb.edu.pl. 
of taxpayers concerning the issue of complying with or neglecting their duties as taxpayers anchored in tax mentality and the awareness of being a citizen" (Kilchler, 2007: 99). The problem of tax morale is not analyzed through legal sciences which have fundamental importance regarding creation and tightening of the tax system and having special significance to tax gap limitation ${ }^{2}$ (Gemmell, Hasseldine, 2012), as well as to a broad fiscal security of the state and public financial interest. Therefore, the aim of this article is to determine what values taxpayers are guided by when deciding to comply with or evade due taxes and what factors shape their tax motivation. Among moral values indicated by L. Huberts (2014: 85), as public values significant from the perspective of tax compliance may be considered such as public interest, the common good, the interest of the future generations, rule of law, honesty, justice, dignity, ethical awareness and moral standards. The research problem of the article is to establish the answer to the question, essential in the context of paying taxes, whether tax motivation may protect the public financial interest. Given such stated research problem, the hypothesis is formulated in the following way: public financial interest is more protected if taxpayers are ethically motivated to fulfill tax obligations.

Qualitative surveys ${ }^{3}$ were used to verify the hypothesis, conducted on the sample $\mathrm{n}=1300$ inhabitants of Podlaskie and Mazowieckie Provinces, in the age from 18 to 60 , with the return of surveys on the level of $13 \%$. Respondents were asked the following questions including the factors shaping tax motivation both positively $(\mathrm{P})$ and negatively $(\mathrm{N})$ :

1) What motivates entrepreneur to pay taxes? $(P)$

2) What discourages us from using services provided by people or economic entities not paying due taxes? $(P)$

3) Do entrepreneurs honestly pay taxes do so guided by any moral values? If yes then which ones? $(P)$

4) Assuming that your neighbor had their flat renovated by their colleague and did not sign any official agreement evading in this way the payment of taxes, what motivated them? ( $N$ )

5) What motivates us to use services provided by people or economic entities not paying due taxes? ( $N$ )

6) What discourages entrepreneurs from paying taxes? $(N)$

Tax gap is a difference between due taxes which taxpayers should pay in a given time and those which were actually received by the state budget.

3 Preliminary analysis of the presented research results were published by E. Lotko and U.K. Zawadzka-Pąk (2017: 333-343). 


\section{Notion of Public Financial Interest}

According to the lexical definition, the word "interest" may describe "a thing to do" as well as a pursuit to achieve one's own benefit or a benefit for someone else (The Polish language dictionary, 2007: 135). It may be assumed that this benefit is identified with good occurring in a limited amount or directly with material benefits, often financial.

The notion of public interest both in the theory of law and judicial decisions is imprecise and the trials to define it are different depending on the context used or law branches (Wilczyńska, 2009: 50-51; Leszczyński, 2006: 81; Suwaj, 2009: 19; Żurawik, 2013a; Hanusz, Krukowska-Siembida, 2006: 181-184). It may be presumed that the reason for such imprecision is the necessity to consider all circumstances of a given situation every time as well as the need to search for values indicating the scope of individual or public interest and the legislator's intention to implement regulation regarding diverse factual status impossible to formulate in an unequivocal way with the dynamically changing reality (Wilczyńska, 2009: 48). Nevertheless, two different concepts of public interest may be given (Żurawik, 2013: 60). According to the first one, the public interest as opposed to the individual interest. In turn, pursuant to the doctrine of liberal rule of law and the concept of subjective rights, both interests may not only exist parallel to each other but even be connected (Wyrzykowski, 1986: 30-31). Analysing the notion of public interest in the context of taxpayers' behaviors, it is impossible to omit the issues of relations between public and individual interest. There are three models in the professional literature:

- the theory of overriding public interest according to which public interest is superior in relation to the individual interest allowing elimination of minority interest in the process of defining public good;

- common interest theory assuming summing up all individual interests including minority interests;

- unitary conception assuming that the notion of public interest "is founded on the rivalry between competing claims, based however on certain common values accepted in the society and constituting basis for decisions of public authority" (Nawrot, 2009: 67-68).

The notion of public interest may also be determined through the public good, the common good which not always has to correspond to individual good. In the universal apprehension, public interest should be evaluated from the point of view of the common good (society) and the actions of an individual in the aspect of conformity with the interests of other parties (Jakimowicz, 2006: 118). Therefore, discussing acting in the public interest, protection of such values as legal security, 
public order, health care, protection of the environment, protection of liberty and rights of other people as well as fighting frauds and fulfilling tax duties should be taken into account.

In connection with the above, the notion of public financial interest may be understood in two ways: as specific actions in the legal sphere aiming at establishing proper legal provisions allowing to sustain the financial stability of the state or the action of the taxpayers themselves aiming at fulfilling or encouraging to fulfill legal tax duties. For the purpose of this article, the notion of public financial interest is identified with individual reactions of taxpayers to fulfilling tax obligation.

\section{Tax Morale and Tax Motivation}

Tax morale is understood as the internalized obligation (Feld, Frey, 2005) or internal motivation to pay tax liabilities (Alm, Torgler, 2006). On the other hand, taxpayer's morale is understood as an individual reaction to fulfill tax obligation dictated by ethical factors (moral values and attitudes) or psychological factors (reaction of the surroundings / social mentality, legal provisions). Therefore, tax morale and thus taxpayers' behaviors are influenced by their individual financial position, internal beliefs, internal acceptance and recognizing state's fiscal sovereignty (PasternakMalicka, 2013: 92). It needs to be emphasized that tax has always been associated with an unpleasant duty to transfer a part of one's own income to the State Treasury or local government units (Pest, 2010: 107). This obligation may lead to tax resistance (Gomułowicz, Małecki, 2008: 1) which is characterized by a sequence of actions whose aim is to evade paying taxes. Braithwaite (2009: 103) distinguishes two types of resistance against paying taxes, i.e. disrespectful resistance when people think that authorities do not have the right to interfere in the freedom of the individual and attacking resistance meaning opposition to the methods used by the authorities.

It should be unequivocally emphasized that tax resistance results in serious consequences for the financial security of the state and infringes the principle of social justice. It also negatively impacts the fiscal function of taxes and consequently increases the tax gap ${ }^{4}$, because not all public funds which should be transferred are transferred to the state's budget. Therefore, the implementation of the main tax function should be connected with tax motivation in the scope of tax obligations and the phenomenon of social resistance ought to be treated as reprehensible and highly immoral. 4 According to the estimation of PwC, tax gap in the VAT in 2017 in Poland will decrease by about 13 billion PLN
but still, its estimated amount is about 39 billion PLN. 


\section{Analysis of Tax Motivation}

Conducted research was to select factors which positively and negatively shape tax motivation. Answering the first question concerning positive factors shaping tax motivation (among 169 people participating in the research, 159 answered, a part of them gave longer answers from which a few factors were selected, and therefore the number 159 is treated as $100 \%$ ) only $8.1 \%$ of respondents drew the attention to ethical aspects. Occasional answers indicate that respondents have higher values what acknowledge such answers as: "the willingness to conduct responsible business, being perceived as an honest entrepreneur", "the willingness to legally conduct business activity", "honesty towards country and society", "shared responsibility", "honesty", "patriotism". The vast majority of answers considered psychological factors. Respondents indicated that the biggest motivators to pay taxes are: financial penalties for non-payment (50.3\%), fear of fiscal control (6.2\%), own benefits of reductions and tax exemptions (12.5\%) or the possibility "to be creditworthy" in case of a need to obtain a credit (2\%).

Essential factor positively shaping tax motivation, but indicated by only $2.5 \%$ of respondents, are visible effects of the state's activity financed from the tax revenues and the conviction that public funds are well spent. $18.4 \%$ of respondents stated that "nothing" motivates them because paying taxes is a duty imposed by legal provisions. Next question connected with the motivation not to use services provided by people or entities not paying taxes was answered by 147 people (similarly as in the case of the previous question, this number was treated as $100 \%$ ). $78.5 \%$ of respondents showed general reluctance towards such entrepreneurs/frauds, with the main reason for $49 \%$ of respondents being own benefits, because of taxpayers:

- fear the quality of performed service / or its performance at all;

- do not want to be cheated;

- will not have the possibility to complain about the performed service.

$3 \%$ of respondents paid attention to social injustice because "such entrepreneurs enrich at our expense" (3\%). Among common answers (17.7\%) may be noticed and unambiguously judge as positive the tendency of the respondents to abide the law. It is worth mentioning that people who participated in the research indicated also such values as morale, honesty, reluctance to support breaking the law and stealing from the state. However, it is disturbing that only $3.8 \%$ of respondents paid attention to such values. Another question directly concerned moral values guiding entrepreneurs who honestly pay taxes. Answers given by 155 respondents are presented in Figure 1. Especially alarming is the fact that over $29 \%$ of respondents answered that they are not guided by any moral values because it is a duty imposed by law. 


\section{Figure 1 Moral Values Guiding Taxpayers Who Fulfil Tax Obligation}
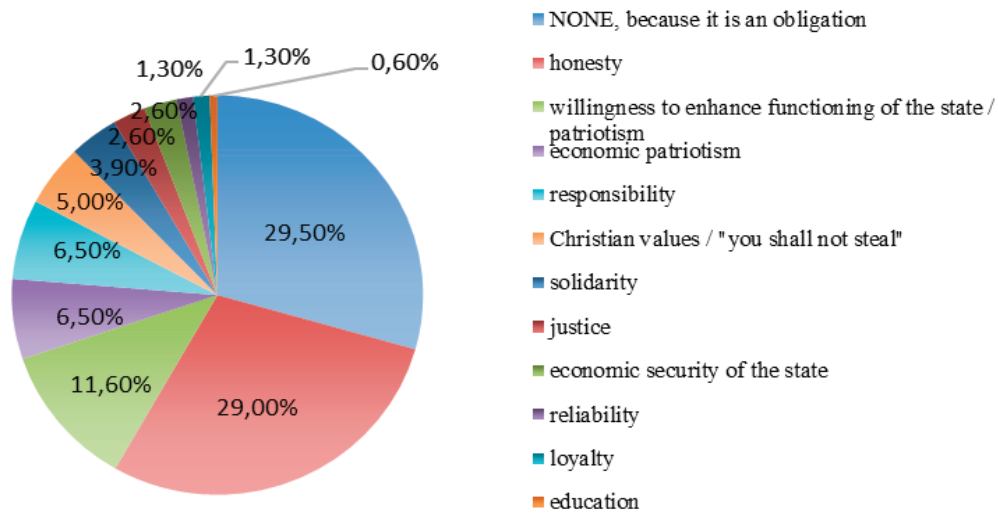

Source: Own elaboration.

Summing up the first three questions, Figures 2 and 3 present collective summaries of factors positively shaping tax motivation with specified psychological and ethical factors. The sum of values for particular factors in both cases exceeds $100 \%$, however calculating percentage value for particular factors, taking into account that each question has the different number of answers or no answers at all, an average of 154 from all answers was assumed and treated as $100 \%$.

Figure 2 Psychological Factors Positively Shaping Tax Motivation

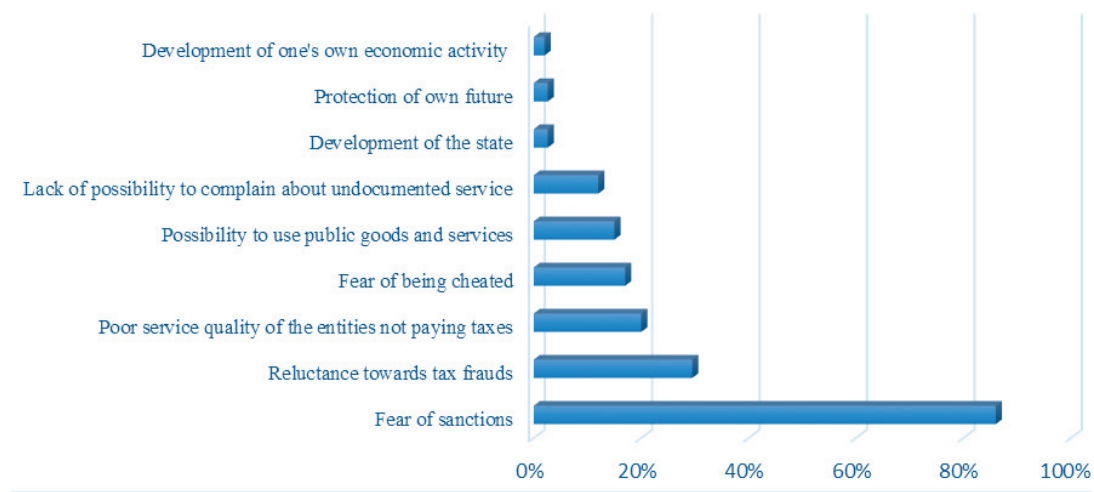

Source: Own elaboration. 
Tax Motivation as an Instrument Protecting Public Financial Interest

Figure 3 Ethical Factors Positively Shaping Tax Motivation

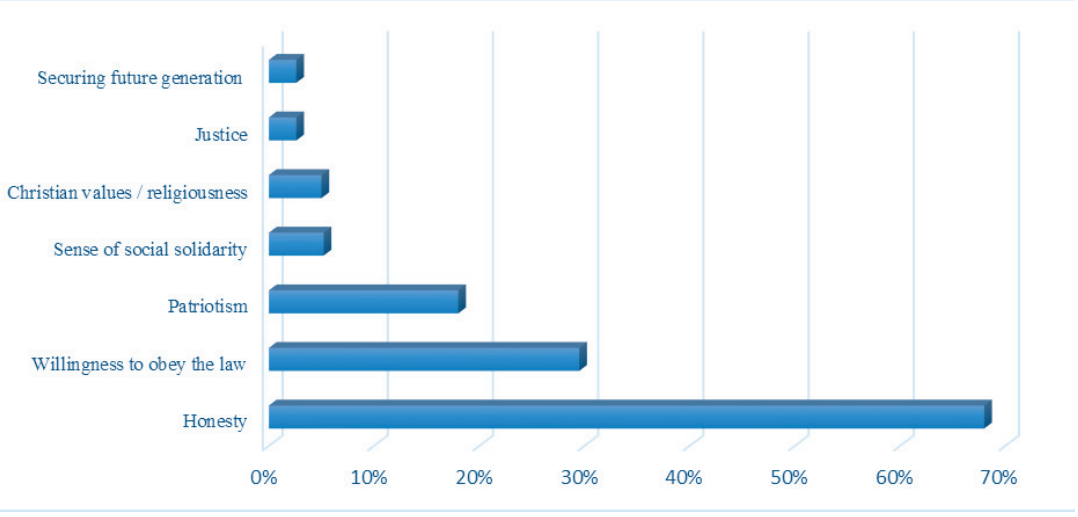

Source: Own elaboration.

Another group of questions allowed to specify the factors which do not motivate taxpayers to pay taxes. The first question was: "assuming that your neighbor had their flat renovated by their colleague and did not sign any official agreement evading paying taxes, what motivated them?" Such asked question was answered by 159 respondents, some of them gave more than one answer to the total sum of answers exceeded $100 \%$. Obtained answers allowed to specify six categories arranged according to their frequency:

1) willingness to save money $-74 \%$,

2) helping a friend $-14 \%$,

3) less formalism and bureaucracy $-10.7 \%$

4) own beliefs / "Polish mentality" $-9.5 \%$

5) lack of knowledge of legal provisions and awareness to enter such agreement $-9 \%$

6) not very friendly state/ attitude of civil servants $-3.8 \%$.

Similar answers regarding the content and frequency were given to the next question concerning taxpayer's motivation to use services provided by people/ entities not paying taxes. Such asked question was answered by 153 respondents. Dominating answers are:

1) lower price connected with the willingness to save $-70 \%$ of respondents,

2) lack of trust to politicians $-23.7 \%$,

3) fast and less formalized service $-3.3 \%$

4) internal reluctance to pay taxes $-3 \%$. 
Whereas among answers to the question about factors discouraging entrepreneurs from paying taxes, four groups of answers were selected from 158 answers:

1) the amount of taxes $-54 \%$,

2) too expanded and complicated tax system $-27 \%$,

3) entrepreneur's attitude/ unwillingness to share $-16.5 \%$

4) the attitude of the state/politicians/ sense of wasting public funds $-8.2 \%$.

The Figures below the present collective summary of the factors negatively influencing tax morale, with division into psychological and ethical. The sum of values for particular factors in both cases exceeded $100 \%$ because the Figures show data from three questions. Calculating percentage value for particular factors, having regard that each question had the different number of answers or no answers at all, an average of 156 answers was assumed and treated as $100 \%$.

\section{Figure 4 Psychological Factors Negatively Shaping Tax Motivation}

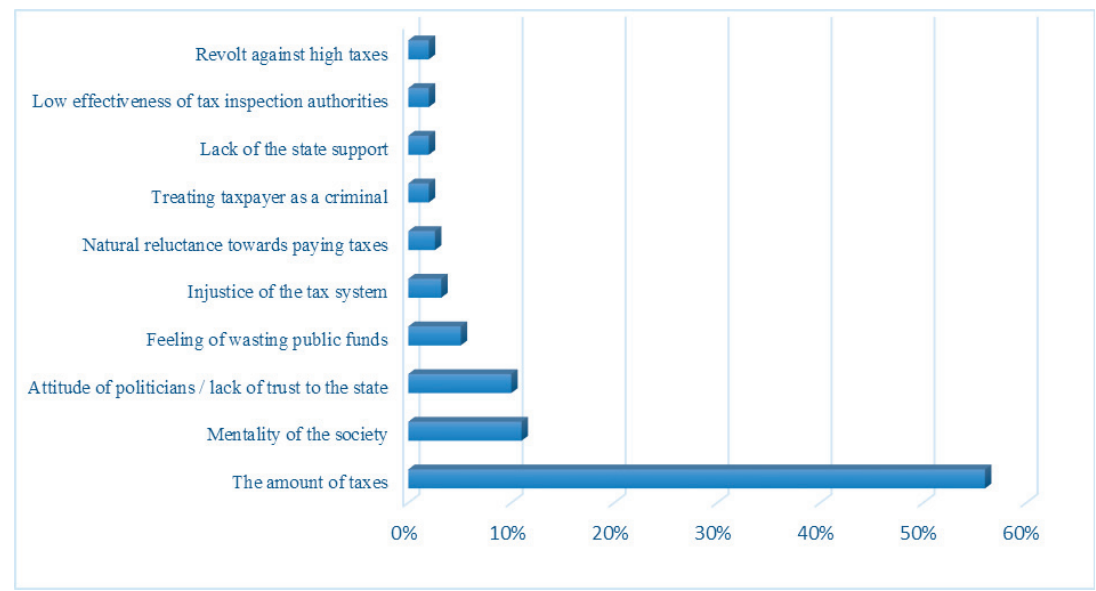

Source: Own elaboration. 


\section{Figure 5 Ethical Factors Negatively Shaping Tax Motivation}

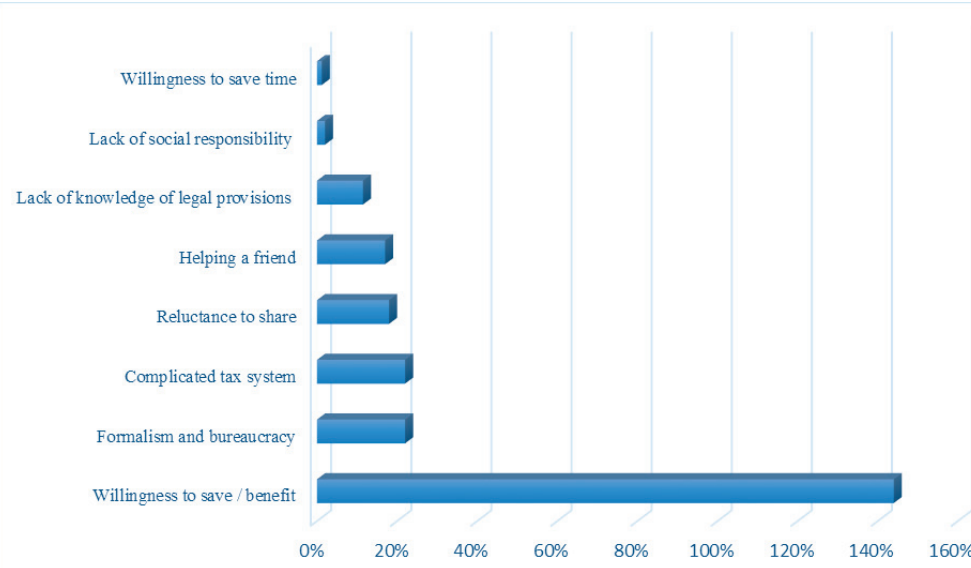

Source: Own elaboration.

\section{Conclusions}

The aim of the article was to determine values which taxpayers are guided by making decision about paying or evading due taxes as well as factors shaping their tax motivation. Regarding obtained results of the research identifying factors shaping tax motivation, psychological and ethical factors were selected, with the former proved to be major in having impact on tax motivation. The main psychological factor negatively influencing tax motivation is the amount of tax and general reluctance towards transferring a part of earned money. The factor deepening negative motivation is the legislator creating the law, who, in the opinion of people participating in the research, does not have a lot of trust from the taxpayers. Additionally, taxpayers (also participating in the research) would like in return for giving away a part of their income to the state see measurable effects of the state activity. Meanwhile, the vast majority of respondents does not perceive reliability, cost-efficiency and purposefulness in using public funds, what in a large extent determines their beliefs and thus behaviour. Among ethical factors negatively shaping tax motivation prevail willingness to obtain own profits and taking care of one's own private interest. Interestingly, respondents on the one hand indicate reluctance towards sharing with the state $(18 \%)$, and on the other hand accept the possibility to help their friend who does not conduct their business in accordance with law (17\%). Also other unethical taxpayers' activities should be highlighted. Mainly, the lack of knowledge of legal provisions, according to respondents, arises from complexity and frequent changes in tax law and not concluding agreements 
and as a result not paying due taxes are justified by too extensive formalism and bureaucracy. Thus, unethical taxpayers' activities are rooted in reluctance to sacrifice own time and in the lack of social and moral responsibility for the state and protection of public financial interest. Among factors positively shaping tax motivation prevail fear from sanctions and uncertainty about the quality of undocumented service. However it is a positively influencing aspect, it is again dictated by own interest of the taxpayer, leaving public financial interest behind. The research also allowed to select moral values which taxpayers are guided by when fulfilling tax obligation. Values such as honesty, willingness to enhance the functioning of the state, justice, patriotism, responsibility and care for common good are present in the taxpayers' awareness. However, as the research indicated, they influence motivation of only $10 \%$ of respondents.

Finally, with regard to the stated research problem, it should be indicated that tax motivation may protect the public financial interest, however, to be an effective instrument, it needs to result from the tax morale. This morale is highly influenced by opinion about the commonness of tax evasion and trust to democratic institutions of the state. The research showed that the actions of the taxpayers themselves as well as the representatives of legislative and executive authorities decide about the will to cooperate and care for common good. Therefore, the connection between tax morale and tax motivation may strengthen tax discipline and consequently public financial interest of the state. However, to make it fully possible, taxpayers should be motivated mainly by ethical factors positively shaping tax motivation.

Moreover, there is a need to increase tax awareness of the society and its education regarding public finances. A society whose members from yearly years learn about the needs of the state, relevance of participating in decisions concerning its functioning and economic processes is a society with high public awareness which impacts shaping of tax morale. It is in the public interest to form tax morale in such a way that taxpayers do not evade tax duties and fulfil them with the sense of acting in public interest. Although legal provisions do not impose priority of any interests because the legislator does not unambiguously define the primacy of one interest over the other, but in the situation of evading taxation public interest should be more significant and valuable. If the obligation to pay taxes arises from legal regulation and pursues to achieve objectives intended by the legislator, protects public financial interest and its amount stays in the proper proportion, then fulfilling tax duties should be treated as s value of supra-individual character. Therefore, in making taxpayers' choice, which are usually profit and loss calculations understood as objective, intended and deliberate choice, not without significance is the level of their tax morale which in consequence decides about tax motivation. 


\section{References}

Alm, J., Torgler, B.: Culture differences and tax morale in the United States and in Europe, Journal of Economic Psychology no. 27 (2006).

Braithwaite, V.: Defiance in Taxation and Governance Resisting and Dismissing authority in a Democracy, Cheltenham, Northampton: Edward Elgar, 2009.

Feld, L., Frey, B.S.: Tax compliance as the result of a psychological tax contract: The role of incentives and responsive regulation, CFRSI Working Paper no. 76 (2005).

Gemmell, N., Hasseldine, J.: The Tax Gap: A Methodological Review, Advances in Taxation vol. 20 (2012).

Gomułowicz, A., Małecki, J.: Podatki i prawo podatkowe (Taxes and tax law), Warszawa: LexisNexis, 2008.

Hanusz, A., Krukowska-Siembida, P.: Ważny interest podatnika i interes publiczny w klauzulach generalnych Ordynacji podatkowej (Important interest of the taxpayer and public interest in general clauses of the Tax ordinance), Annales Universitatis Mariae Curie-Skłodowska Lublin - Polonia no. 2 (2016), DOI 10.17951/g.2016.63.2.181.

Huberts, L. (ed.): The Integrity of Governance, What it is, What We Know, What is Done, and Where to Go, London: Palgrave Macmillan, 2014.

Jakimowicz W.: Wykładania w prawie administracyjnym (Interpretation in administrative law), Warszawa: Wolters Kluwer, 2006.

Kirchler, E.: The economic psychology of tax behaviour, Cambridge: Cambridge University Press, 2007.

Leszczyński, L.: Kategoria interesu w stosowaniu prawa administracyjnego. Przykład art. 7 KPA (The category of interest in the application of administrative law. Example of Art. 7 of the Code of Administrative Proceedings), in: Korybski, A., Kostyckij, M.W., Leszczyński, L. (eds.): Pojęcie interesu $w$ naukach prawnych, prawie stanowionym i orzecznictwie sądowym Polski i Ukrainy (The notion of interest in legal sciences, codified law and judicial decisions of Poland and Ukaraine), Lublin: Wydawnictwo Uniwersytetu Marii CurieSkłodowskiej, 2006.

Lotko, E., Zawadzka-Pąk, U.K.: Psychologiczne i etyczne aspekty w kształtowaniu motywacji podatkowej (Psychological and Ethical Aspects in Shaping Tax Morale), Przedsiębiorczość i zarządzanie w rozwoju ekonomicznym (Entrepreneurship and management in economic development) no. 2 (2017).

Nawrot, J.: Interes publiczny (Public interest), in: Powałowski, A. (ed.): Leksykon prawa gospodarczego publicznego (Lexicon of public economic law), Warszawa: C.H. Beck, 2009.

Niesiobędzka, M.: Dlaczego nie płacimy podatków? Psychologiczna analiza uchylania się od opodatkowania (Why don't we pay taxes? Psychological analysis of tax evasion), Warszawa: Scholar, 2013. 
Pasternak-Malicka, M.: Mentalność i moralność podatkowa a reakcje gospodarstw domowych na obowiązek podatkowy (Mentality, tax morale and reactions of households to tax obligation), Modern Management Review no. 1 (2013).

Pest, P.: Mechanizmy powstawania oporu podatkowego (Mechanisms of tax resistance formation), Studenckie Prace Prawnicze, Administratywistyczne i Ekonomiczne (Students' Legal, Administrative and Economic Works) no. 8 (2010).

Słownik Języka Polskiego (The Polish language dictionary), Warszawa: Wydawnictwo Naukowe PWN, 2007.

Suwaj, P.J.: Konflikt interesów w administracji publicznej (Conflict of interests in public administration), Warszawa: Oficyna a Wolters Kluwer business, 2009.

Wilczyńska, A.: Interes publiczny $\mathrm{w}$ prawie stanowionym $\mathrm{i}$ orzecznictwie Trybunału Konstytucyjnego (Public interest in codified law and judicial decisions of the Constitutional Tribunal), Przegląd Prawa Handlowego (The Merchant Law Review) no. 6 (2009).

Wyrzykowski, M.: Pojęcie interesu społecznego w prawie administracyjnym (The notion of social interest in administrative law), Warszawa: Wydawnictwo Uniwersytetu Warszawskiego, 1986.

Żurawik, A.: Interes publiczny”, „Interes społeczny” i „Interes społecznie uzasadniony”. Próba dookreślenia pojęć ("Public interest", "Social interest" and "Socially just interest". A trial to specify the notions), Ruch prawniczy, ekonomiczny i socjologiczny (Legal, economic and sociological movement) no. 2 (2013).

Żurawik, A.: Interes publiczny w prawie gospodarczym (Public interest in economic law), Warszawa: C.H. Beck, 2013a. 